\title{
Micro-Topographies Promote Late Chondrogenic Differentiation Markers in the ATDC5 Cell Line
}

Citation for published version (APA):

Le, B. Q., Vasilevich, A., Vermeulen, S., Hulshof, F., Stamatialis, D. F., van Blitterswijk, C. A., \& de Boer, J. (2017). Micro-Topographies Promote Late Chondrogenic Differentiation Markers in the ATDC5 Cell Line. Tissue Engineering, 23(9-10), 458-469. https://doi.org/10.1089/ten.tea.2016.0421

Document status and date:

Published: 01/05/2017

DOI:

10.1089/ten.tea.2016.0421

Document Version:

Publisher's PDF, also known as Version of record

Document license:

Taverne

Please check the document version of this publication:

- A submitted manuscript is the version of the article upon submission and before peer-review. There can be important differences between the submitted version and the official published version of record.

People interested in the research are advised to contact the author for the final version of the publication, or visit the DOI to the publisher's website.

- The final author version and the galley proof are versions of the publication after peer review.

- The final published version features the final layout of the paper including the volume, issue and page numbers.

Link to publication

\footnotetext{
General rights rights.

- You may freely distribute the URL identifying the publication in the public portal. please follow below link for the End User Agreement:

www.umlib.nl/taverne-license

Take down policy

If you believe that this document breaches copyright please contact us at:

repository@maastrichtuniversity.nl

providing details and we will investigate your claim.
}

Copyright and moral rights for the publications made accessible in the public portal are retained by the authors and/or other copyright owners and it is a condition of accessing publications that users recognise and abide by the legal requirements associated with these

- Users may download and print one copy of any publication from the public portal for the purpose of private study or research.

- You may not further distribute the material or use it for any profit-making activity or commercial gain

If the publication is distributed under the terms of Article $25 \mathrm{fa}$ of the Dutch Copyright Act, indicated by the "Taverne" license above, 


\title{
Micro-Topographies Promote Late Chondrogenic Differentiation Markers in the ATDC5 Cell Line
}

\author{
Bach Q. Le, MSc,' Aliaksei Vasilevich, MSc, Steven Vermeulen, MSc, Frits Hulshof, PhD, \\ Dimitrios F. Stamatialis, $\mathrm{PhD}^{3}$, Clemens A. van Blitterswijk, $\mathrm{PhD}^{1,4}$ and Jan de Boer, $\mathrm{PhD}^{2}$
}

Chemical and mechanical cues are well-established influencers of in vitro chondrogenic differentiation of ATDC5 cells. Here, we investigate the role of topographical cues in this differentiation process, a study not been explored before. Previously, using a library of surface micro-topographies we found some distinct patterns that induced alkaline phosphatase (ALP) production in human mesenchymal stromal cells. $A L P$ is also a marker for hypertrophy, the end stage of chondrogenic differentiation preceding bone formation. Thus, we hypothesized that these patterns could influence end-stage chondrogenic differentiation of ATDC5 cells. In this study, we randomly selected seven topographies among the ALP influencing hits. Cells grown on these surfaces displayed varying nuclear shape and actin filament structure. When stimulated with insulin-transferrin-selenium (ITS) medium, nodule formation occurred and in some cases showed alignment to the topographical patterns. Gene expression analysis of cells growing on topographical surfaces in the presence of ITS medium revealed a downregulation of early markers and upregulation of late markers of chondrogenic differentiation compared to cells grown on a flat surface. In conclusion, we demonstrated that surface topography in addition to other cues can promote hypertrophic differentiation suitable for bone tissue engineering.

Keywords: surface topography, chondrogenesis, hypertrophy, ATDC5, cell morphology

\section{Introduction}

$\mathbf{S}_{\mathrm{s}}$ URFACE MICRO/NANO-TOPOGRAPHY is increasingly recognized as an important element in the design of medical implants to obtain the intended functionality. Cell-material interaction is not only influenced by chemistry, but is also dependent on the physical events occurring at the cellmaterial interface. Various studies have shown the effect of surface topography on cell fate decision in vitro. ${ }^{1-4}$ Many attempts have been made to modify implant surface for better biocompatibility and integration of the host tissue..$^{5-7}$

Surface topography is no stranger in the field of bone tissue engineering. As mentioned in the review of Wennerberg and Albrektsson, ${ }^{8}$ as early as the beginning of the 1980 s, surface structure was identified as one of the factors particularly important for the incorporation of implants into bone. Rougher surfaces had a more beneficial effect for osteointegration over smooth surfaces, due to the larger surface area of the former. ${ }^{9}$
Later, advances in micro and nanotechnology enabled researchers to create precision-designed surface topography, starting a new field of material surface topography. Dalby et al. used electron beam lithography to fabricate nanoscale topographical surfaces featuring 120-nm-diameter, 100-nmdeep nanopits placing from highly ordered symmetries to somewhat random placements. ${ }^{2}$ Interestingly, they discovered that the random-placed nanopit topography stimulated human mesenchymal stem cells (hMSCs) to produce bone mineral in vitro without any osteogenic supplement. Although not specifically biomimetic, as declared by the authors, this approach is clearly useful in the regenerative medicine framework.

To expand the effort in elucidating the instructive power of surface topography, we previously created a topographyscreening platform, the TopoChip, consisting of 2176 distinct surface topographies on a $2 \times 2 \mathrm{~cm}$ chip. In one TopoChip screen, we identified topographies that induce alkaline phosphatase (ALP) production from hMSCs. ${ }^{10}$ Since $A L P$ is also

\footnotetext{
${ }^{1}$ Department of Tissue Regeneration, MIRA Institute, University of Twente, Enschede, The Netherlands.

${ }^{2}$ Laboratory for Cell Biology-inspired Tissue Engineering, MERLN Institute, University of Maastricht, Maastricht, The Netherlands.

${ }^{3}$ Department of Biomaterials Science and Technology, MIRA Institute, University of Twente, Enschede, The Netherlands.

${ }^{4}$ Department of Complex Tissue Regeneration, MERLN Institute, University of Maastricht, Maastricht, The Netherlands.
} 
a marker for hypertrophic differentiation of chondrocytes, ${ }^{11}$ we hypothesized that these topographies could influence the different stages of chondrocyte differentiation.

Previously, we have successfully tissue-engineered hypertrophic cartilage in vitro using embryonic stem cells. ${ }^{12}$ However, because of ethical controversy and the potential hazard of teratoma formation, we are interested in further exploring different methods of manipulating chondrocyte differentiation and extracellular matrix (ECM) deposition. In preceding studies, we used the ATDC5 chondroprogenitor cell line, an in vitro model system that has been used extensively in cartilage and bone research. ${ }^{13}$ Our goal is to aid the field of bone tissue engineering by utilizing ATDC5 as a workhorse to produce hypertrophic cartilage matrix in vitro, which can be used in vivo with/without decellularization for endochondral ossification. To increase yield, we performed a screen of the LOPAC-1280 drug library and discovered tetradecylthioacetic acid as a drug that enhances collagen production by ATDC5. ${ }^{14}$ In another approach, we employed a microwell platform to culture ATDC5 in small aggregates of 1000 cells, resulting in a better and more homogeneous cartilage matrix than cells growing on common tissue culture-treated plates (article submitted).

During the development of an ATDC5 monolayer on a flat surface, when exposed to ITS medium, spots of cell aggregates appear randomly across the surface due to hyperplasia. This is concomitant with a series of differentiation events characterized by an increase in expression of chondrogenic markers. The ATDC5 cell line is extensively used to study the effect of micro-environment modifications on this chondrogenic differentiation process. Examples include the use of growth factors, ${ }^{15}$ ascorbic acid, ${ }^{16}$ oxygen tension, ${ }^{17}$ and substrate stiffness. ${ }^{18}$ In this study, we further extend these different approaches by studying the effect of surface topographies during the chondrogenesis of ATDC5 cells. Surface micro-topography has been known to affect cell shape, spreading, ${ }^{19}$ and differentiation. ${ }^{20}$ But whether surface micro-topography can affect the chondrogenic differentiation process is unknown. Instead of using the full TopoChip, we opted to select seven topographies from the hits of our previous TopoChip screen. These hits had a profound positive and negative effect on ALP secretion of hMSCs (article submitted). The seven topographies were fabricated on discs with a diameter of $1.5 \mathrm{~cm}$, allowing the use of traditional molecular biology techniques such as quantitative polymerase chain reaction. We wanted to explore the relationship between cell/nuclei shape and gene expression profile of chondrogenesis-related genes. Ultimately, we asked what particular surface topography would induce a specific cell morphology, which in turn would influence the pathway to hypertrophic differentiation of ATDC5 cells.

\section{Materials and Methods}

\section{Cell culture}

ATDC5 cells were obtained from RIKEN cell bank (Japan). Basic medium (BM) for ATDC5 consisted of DMEM/ F-12 GlutaMAX (Life Technologies), 5\% v/v fetal bovine serum (Lonza), $0.2 \mathrm{mM}$ L-ascorbic acid-2 phosphate, $100 \mathrm{U} / \mathrm{mL}$ of penicillin, and $100 \mu \mathrm{g} / \mathrm{mL}$ of streptomycin. To stimulate chondrogenic differentiation and nodule formation, an insulin-transferrin-selenium (ITS) solution $(100 \times$; Life
Technologies) was supplemented to BM. Cells were grown at $37^{\circ} \mathrm{C}$ in a humid atmosphere with $5 \% \mathrm{CO} 2$. Medium was refreshed two to three times per week and cells were used for further subculturing or cryopreservation upon reaching near confluence.

\section{Producing large topographical surfaces}

Topographies with a feature height of $10 \mu \mathrm{m}$ were produced on polystyrene (PS) by hot embossing of a PS film (Goodfellow). The inverse structure of the topographies was produced on silicon by standard photolithography and deep reactive etching as described before. ${ }^{10}$ The silicon imprint was used to make a positive mould on polydimethylsiloxane (PDMS). The PDMS mould was required to create a second negative mould in OrmoStamp ${ }^{\circledR}$ hybrid polymer (micro resist technology Gmbh), which serves as the mould for hot embossing the PS films. The fabrication of the OrmoStamp mould was necessary due to the fact that demoulding of PS from silicon often led to destruction of the mould. The hot embossing conditions were $140^{\circ} \mathrm{C}$ for $5 \mathrm{~min}$ at a pressure of 10 Bar, with a demoulding temperature of $90^{\circ} \mathrm{C}$. Before cell culture, the PS topographies were briefly treated with oxygen plasma to improve cell adhesion. Plasma treatment was performed for $30 \mathrm{~s}$ at $75 \mathrm{mTor}, 50 \mathrm{sccm} \mathrm{O}$, and $50 \mathrm{~W}$. Topographical numbering is based on our TopoUnit database, a repository containing the design parameters for each individual topography.

\section{DAPI and Phalloidin staining}

Before any experiment, all topographical surfaces and flat control were prewetted in BM for $48 \mathrm{~h}$ at $37^{\circ} \mathrm{C}$. ATDC5 were seeded at a density of $2.10^{4}$ cells $/ \mathrm{cm}^{2}$ in BM on the different surfaces. After $24 \mathrm{~h}$, the surfaces were washed briefly with phosphate-buffered saline (PBS) and then fixed in $4 \%$ paraformaldehyde (Merck) in PBS for $10 \mathrm{~min}$. This was followed by a permeabilization step with $0.1 \%$ Triton X-100 (Sigma-Aldrich) in PBS for $10 \mathrm{~min}$, and then blocking in 5\% BSA (Sigma-Aldrich) for $30 \mathrm{~min}$. After that, the surfaces were incubated for $1 \mathrm{~h}$ in the dark with Alexa Fluor 594 Phalloidin (1:200; Life Technologies) containing 0.03\% Triton X-100 in PBS. After washing with PBS $(3 \times 10 \mathrm{~min})$, the surfaces were incubated with DAPI (1:100 in PBS; Life Technologies) for $10 \mathrm{~min}$ in the dark. After another wash with PBS, the surfaces were mounted on glass slides with Mowiol (Sigma-Aldrich) and left to dry overnight in the dark at room temperature.

\section{Image acquisition and analysis}

Fixed samples were inverted and fluorescent images were acquired through the glass coverslip using a BD pathway microscope and analyzed with CellProfiler. ${ }^{21}$ Fluorescent images were taken with and without cells to confirm the absence of imaging artefacts due to the topographical features. To perform automated image analysis in CellProfiler, a robust pipeline was built to objectively analyze every cell from an image set of at least five images, consisting of no less than 100 cells per condition. After illumination corrections, nuclei morphology was captured using the Otsu adaptive thresholding method applied on the DAPI staining. Subsequently, cell morphology was determined using Otsu 
Table 1. Primers Used in Quantitative Polymerase Chain Reaction Analysis

\begin{tabular}{|c|c|}
\hline Name & Primer sequence \\
\hline Mouse $B 2 m$ & $\begin{array}{l}\text { 5'-CATGGCTCGCTCGGTGACC-3' } \\
\text { 5'-AATGTGAGGCGGGTGGAACTG-3' }\end{array}$ \\
\hline Mouse collagen II alpha & $\begin{array}{l}\text { 5'-CAAGGCCCCCGAGGTGACAAA-3' } \\
\text { 5'-GGGGCCAGGGATTCCATTAGAGC-3' }\end{array}$ \\
\hline Mouse collagen $X$ alpha & $\begin{array}{l}\text { 5'-CATAAAGGGCCCACTTGCTA-3' } \\
\text { 5'-TGGCTGATATTCCTGGTGGT-3' }\end{array}$ \\
\hline Mouse aggrecan & $\begin{array}{l}\text { 5'-AGAACCTTCGCTCCAATGACTC-3' } \\
\text { 5'-AGGGTGTAGCGTGTGGAAATAG-3' }\end{array}$ \\
\hline Mouse $\operatorname{Sox} 9$ & $\begin{array}{l}\text { 5'-CCACGGAACAGACTCACATCTCTC-3' } \\
\text { 5'-CTGCTCAGTTCACCGATGTCCACG-3' }\end{array}$ \\
\hline Mouse HifI alpha & $\begin{array}{l}\text { 5'-TGCTCATCAGTTGCCACTTC-3' } \\
\text { 5'-TGGGCCATTTCTGTGTGTAA-3' }\end{array}$ \\
\hline Mouse HiffII alpha & $\begin{array}{l}\text { 5'-TGAGTTGGCTCATGAGTTGC-3' } \\
\text { 5'-CTCACGGATCTCCTCATGGT-3' }\end{array}$ \\
\hline Mouse Alp & $\begin{array}{l}\text { 5'-AACCCAGACACAAGCATTCC-3' } \\
\text { 5'-GAGACATTTTCCCGTTCACC-3' }\end{array}$ \\
\hline Mouse $M m p 13$ & $\begin{array}{l}\text { 5'-AGGCCTTCAGAAAAGCCTTC-3' } \\
\text { 5'-TCCTTGGAGTGATCCAGACC-3' }\end{array}$ \\
\hline
\end{tabular}

ALP, alkaline phosphatase.

FIG. 1. Visualization of ATDC5 cells grown on distinct surface topographies. (a) Bright-field images of the selected surface topographies. (b) Composite images of ATDC5 cells show the effect of micro-structures on cell and nuclear morphology. Co-staining with markers for nucleus (DAPI) and actin (Phalloidin) were performed $24 \mathrm{~h}$ after seeding. The scale bar represents $50 \mu \mathrm{m}$. DAPI, 4'-6diamidino-2-phenylindole. a
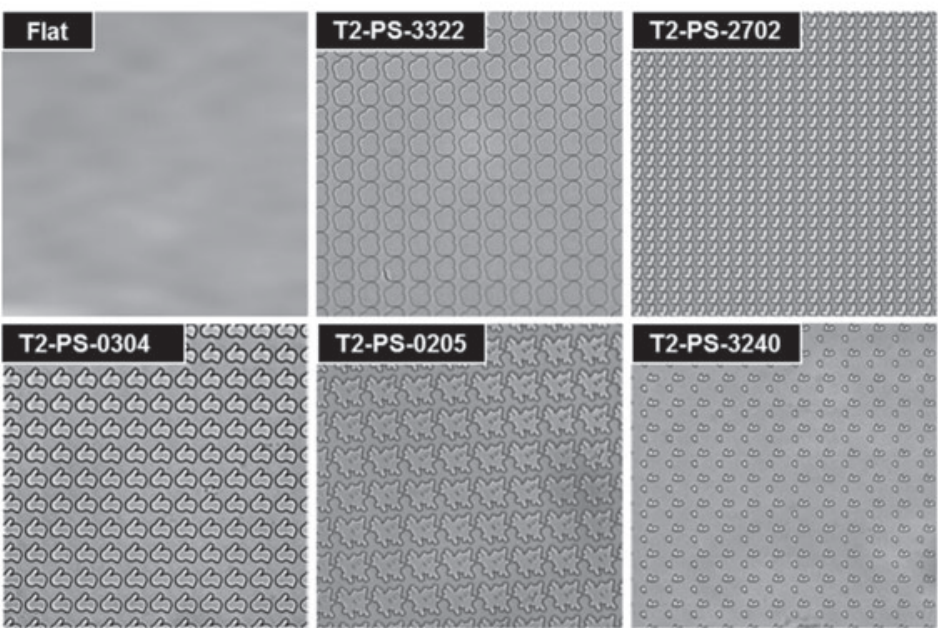

T2-PS-0205
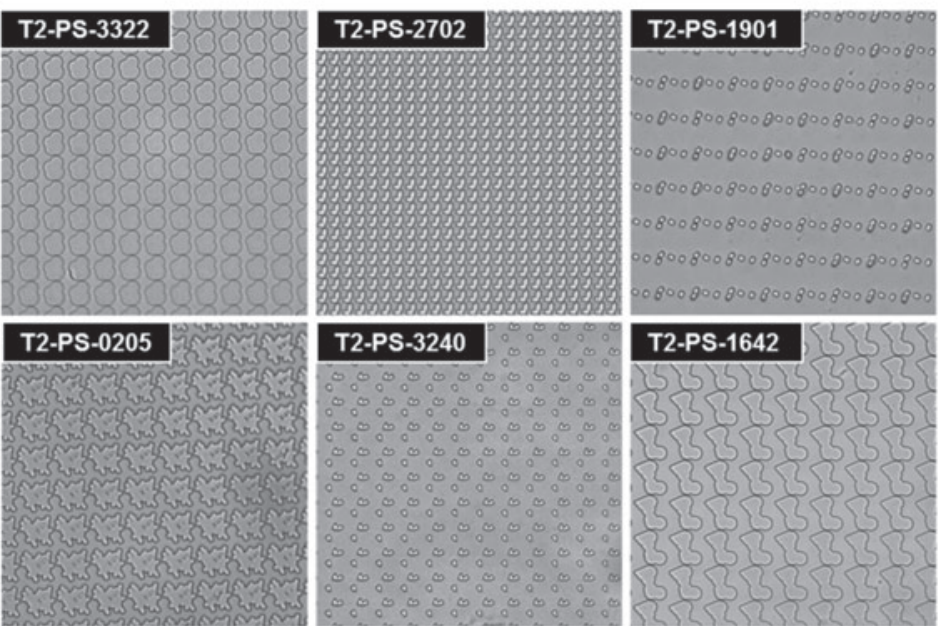

b
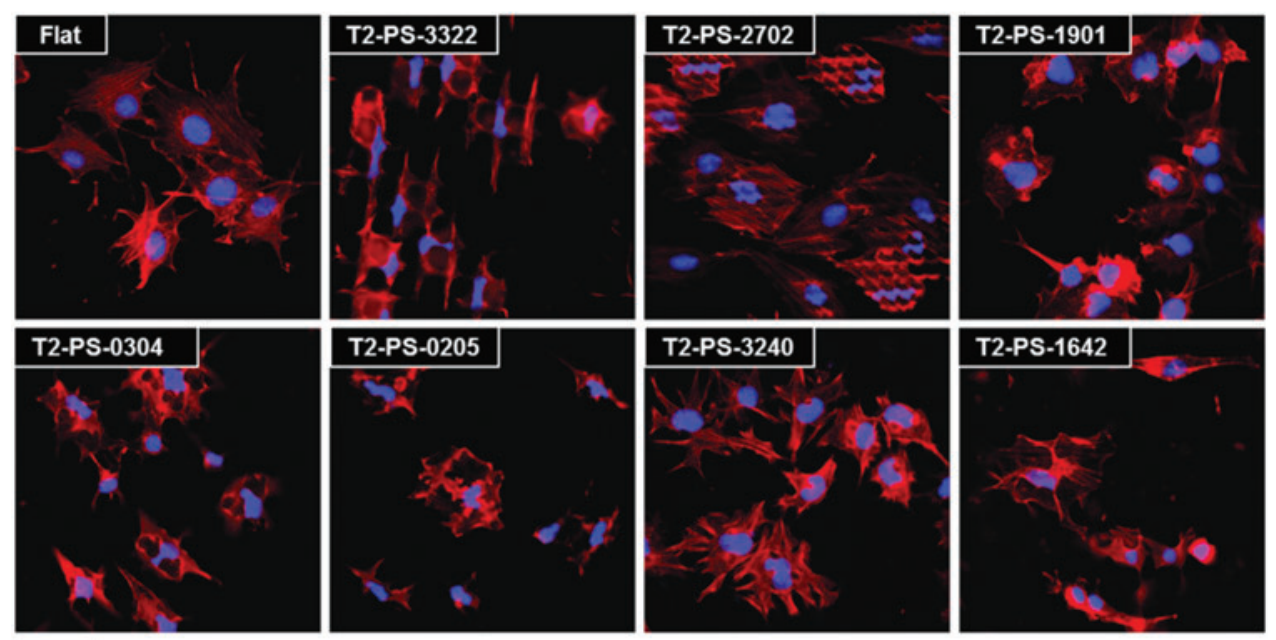
adaptive thresholding and appropriate propagation algorithms. Fifteen cell features were extracted including area, compactness, eccentricity, Euler number, extent, form factor, axis length (major and minor), Feret diameter (max and min), radius (max, mean and median), orientation, perimeter, and solidity. A full explanation of these features is available in the supplementary data file 1. Pixel measurements were converted toward the micrometer dimension using a conversion factor of $0.3 \mu \mathrm{m} / \mathrm{pixel}$.

\section{Gene expression analysis}

ATDC5 cells were seeded at $5.10^{3}$ cells $/ \mathrm{cm}^{2}$ and cultured on seven topographical and a flat (control) surface in BM or ITS medium for 1 or 2 weeks. This experiment was performed in triplicate. RNA was isolated using the RNA II nucleospin RNA isolation kit (Machery Nagel) following the manufacturer's protocol. RNA concentrations were measured using a ND100 spectrophotometer (Nanodrop1000). Reverse transcription was performed with an iScript cDNA synthesis kit according to the manufacturer's protocol. qPCR was performed using $50 \mathrm{ng}$ of cDNA, $0.4 \mu \mathrm{M}$ of each forward and reverse primer (Sigma Genosys), and $1 \times$ Sen-
siMix SYBR and Fluorescein master mix (Bioline). Primer sequences are shown in Table 1. Quantitative polymerase chain reaction (qPCR) was performed in a My IQ5 machine (Biorad). Data were analyzed using the fit point method of My IQ5 software with the baseline set automatically at the lower log-linear part and the cycle threshold (Ct value) was determined. $\mathrm{Ct}$ values were normalized to the Beta- 2 microglobulin $(B 2 m)$ housekeeping gene and $\Delta \mathrm{Ct}(\mathrm{Ct}$, control- $\mathrm{Ct}$, sample) was used to calculate the fold change in gene expression.

\section{Statistical analysis}

Data analysis and plotting were performed in $\mathrm{R}^{22}$ and GraphPad Prism version 6.02 for Windows, GraphPad Software, La Jolla, CA, www.graphpad.com. Cell and nuclear morphological features were scaled by subtracting mean and division by SD. To perform clustering analysis, a dissimilarity matrix was calculated from scaled features in the Euclidean space. For performing hierarchical clustering, Ward's algorithm was implemented. Statistical significance of morphological features and gene expression data of different topographies compared to control was analyzed by analysis of variance followed by Tukey HSD test. For a
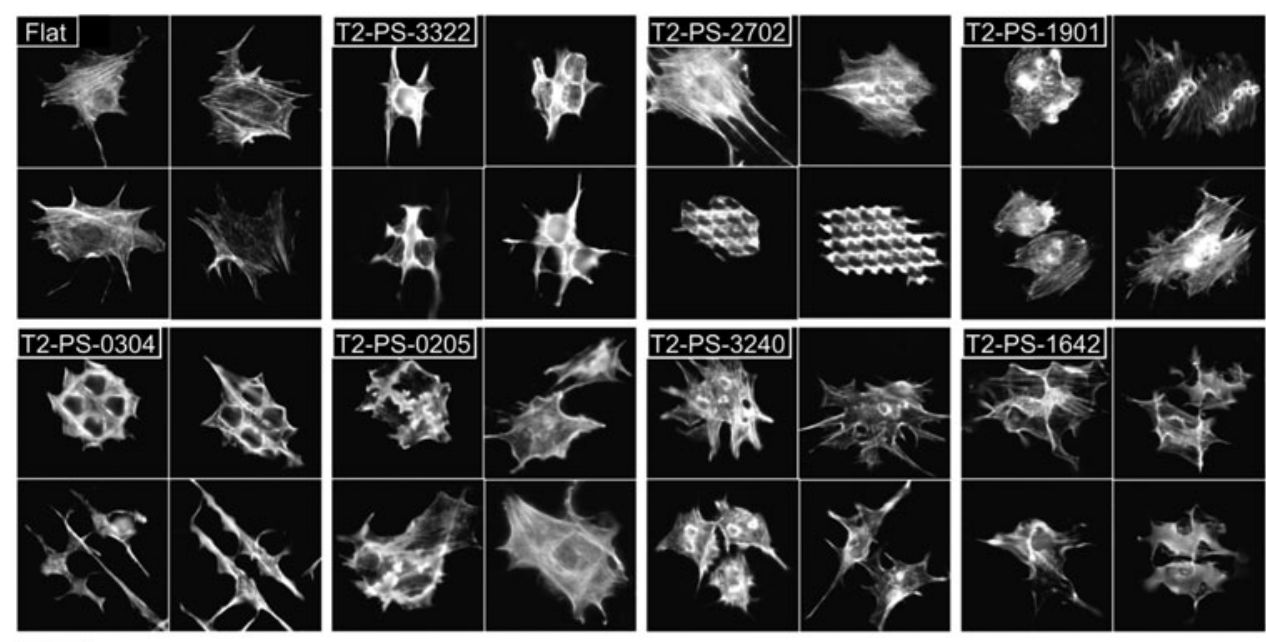

b
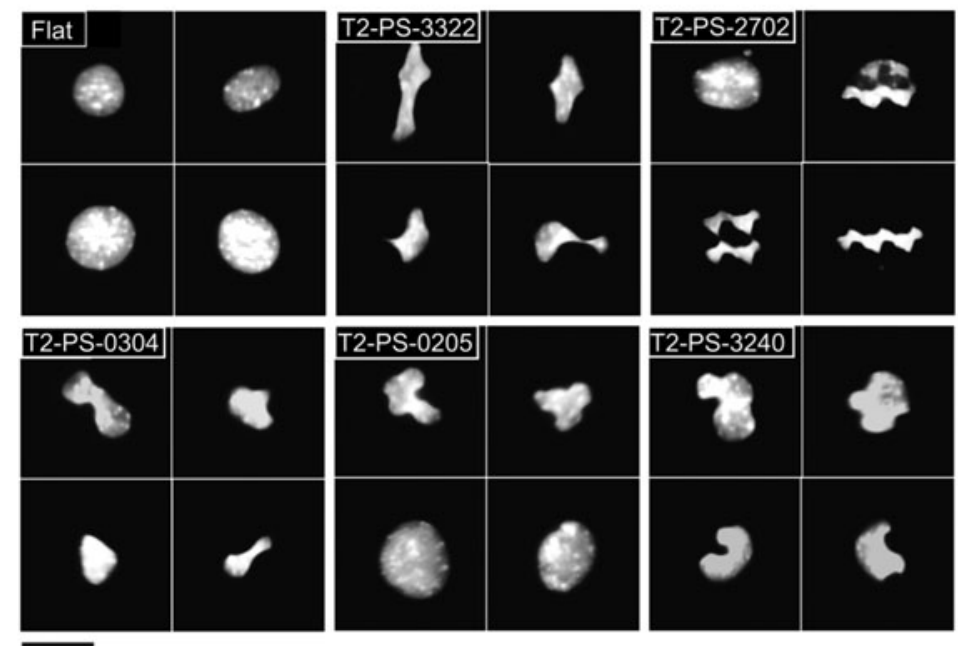

FIG. 2. Visualization of ATDC5 cell and nuclear morphological diversity after culturing $24 \mathrm{~h}$ in BM. Distinct cell and nuclear morphology are present in T2PS-2702 and T2-PS-0205. (a) Immunocytochemistry with a marker for actin (Phalloidin). The scale bar represents $50 \mu \mathrm{m}$. (b) Marker for nuclei (DAPI). The scale bar represents $25 \mu \mathrm{m}$. BM, basic medium; PS, polystyrene. 
$p$-value plot, Mann-Whitney $U$ test was applied and $p$ values were adjusted using Benjamini and Hochberg correction methods.

\section{Model training}

To find unique morphological parameters of cells growing on T2-PS-3322 compared to the other topographies, we used classification trees algorithms from the "rpart" package implemented in R. To explore this further we created a machine learning model. To compensate for differences in cell numbers between conditions, the pooled topography data were downsampled by random selection to have an equal number of data between datasets. To exclude possible bias that might be introduced during downsampling, the model was trained 100 times. Models were trained with 10fold cross validation in the "caret" package using random forest algorithm. Model accuracy was checked on a subset of the data that was not used for training. The classification tree was visualized using the "party" package.

\section{Results}

\section{Surface micro-topographies guide cell and nucleus shape}

It has been shown before that surface topographies (micro and nano) directly control cell morphology. ${ }^{23-25}$ Here, we showed that our surface micro-topographies molded ATDC5 cells into many different sizes and shapes. The cells were cultured in BM on seven different topographical surfaces (Fig. 1a) on discs with a $1.5 \mathrm{~cm}$ diameter with flat PS as a control surface. Topographical surfaces were annotated with their unique feature identifier, derived from the TopoChip database. After $24 \mathrm{~h}$ for the cells to adapt and spread on the surfaces, samples were fixed and stained with Phalloidin and 4'-6-diamidino-2-phenylindole (DAPI) to visualize cell and nucleus structure. Representative pictures of ATDC5 cells grown on the different surfaces are shown in Figure 1b. In general, the cell and nucleus shape on micro-topographical surfaces were distinctively affected by the topographies.

Figure 2a shows the most common types of cell shapes found on every surface. On the control flat PS surface, ATDC5 cells displayed their characteristic epithelial-like morphology, with unpolarized spreading. On topographical surfaces, the actin filaments were more intensely stained, particularly the parts that were in direct contact with the topography features. Interestingly, on T2-PS-2702, two distinct types of cells could be observed, one was similar to the cells on the control surface while the other resembled the pattern of the topographical feature (Fig. 2b-T2-PS-2702). There were also cells that appeared to be in the transition between control-surface-like to topography-like (Fig. 2a-T2PS-2702, top right). Representative nuclear types on each surface are shown in Figure 2b. Apart from the control surface, where nuclei displayed their regular textbook oval shape, the nuclei on other surfaces appeared to be irregular. In most cases, these nuclei took shape while they had to settle between the topographical features. For T2-PS-2702 and T2-PS-0205, several distinct types of nuclei existed on one topographical surface. The transitioning from controlsurface-like to topography-like of cells on T2-PS-2702 could also be seen with their nuclei (Fig. 2b-T2-PS-2702).

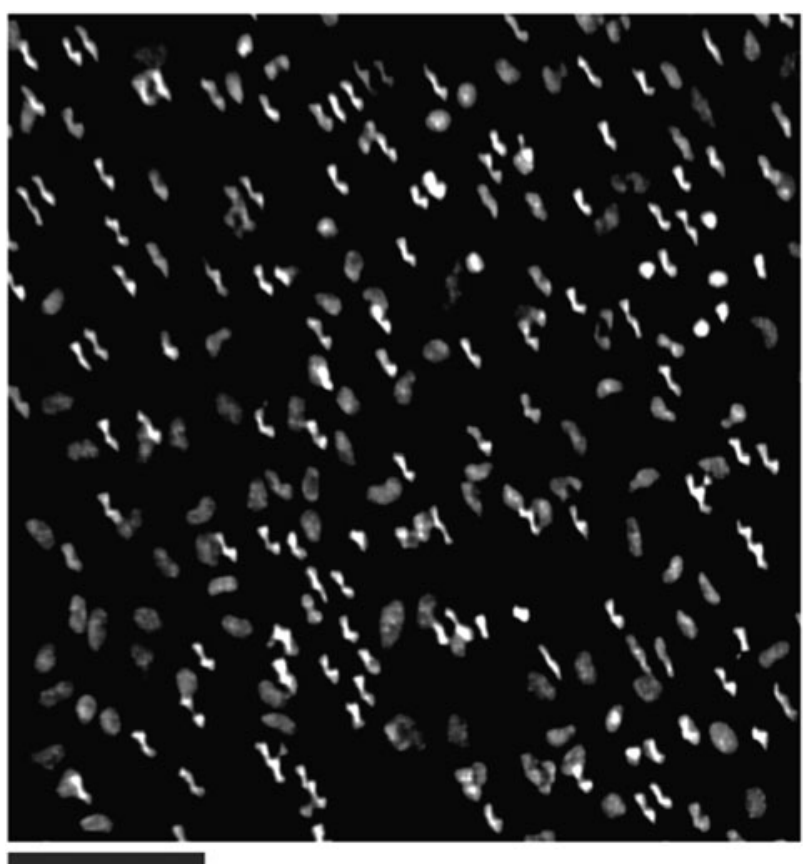

FIG. 3. Long-term culturing of ATDC5 on T2-PS-2702 reveals a consistent pattern of two distinct nuclei. DAPI staining was performed 2 weeks after culturing. Scale bar represents $100 \mu \mathrm{m}$.

Surprisingly, even after 2 weeks of culture this nuclear shape variation remained (Fig. 3), despite that cell shape became unrecognizable because of over-confluency (data not shown). In short, ATDC5 cells and their nuclei exhibited a variety of size and shape when cultured on our microtopographical surfaces.

\section{Quantification of size and shape features by image analysis}

To extract cell and nuclear shape information, we constructed a CellProfiler pipeline to automatically analyze every cell in a dataset of at least 100 cells for each topographical surface. Figure 7a represents cell and nuclear morphology quantification in the form of scaled connected dot plots, while Figure $7 \mathrm{~b}$ illustrates the statistical significance of morphological features of surfaces compared to flat. Notched box plot depiction of cell and nuclear morphology features can be found in Supplementary Figures S1 and S2 (Supplementary Data are available online at www .liebertpub.com/tea), respectively. In total, 30 parameters were calculated that described both cell and nuclear morphology in great detail. Almost no significant differences in cell parameters could be observed between the control surface and T2-PS-2702, which is due to the variability caused by two distinct cell types. Regarding cell size, cells on control surface had the biggest size while scoring highest on the cell size measurements perimeter, radius (maximum, mean and median), minor axis length, and minimum Feret diameter. Cells with the smallest surface belonged to T2-PS3322, T2-PS-0304, and T2-PS-1642. Concerning nuclei, those found on flat surface were among the biggest together with nuclei from T2-PS-2702, T2-PS-1901, and T2-PS- 


\section{a}

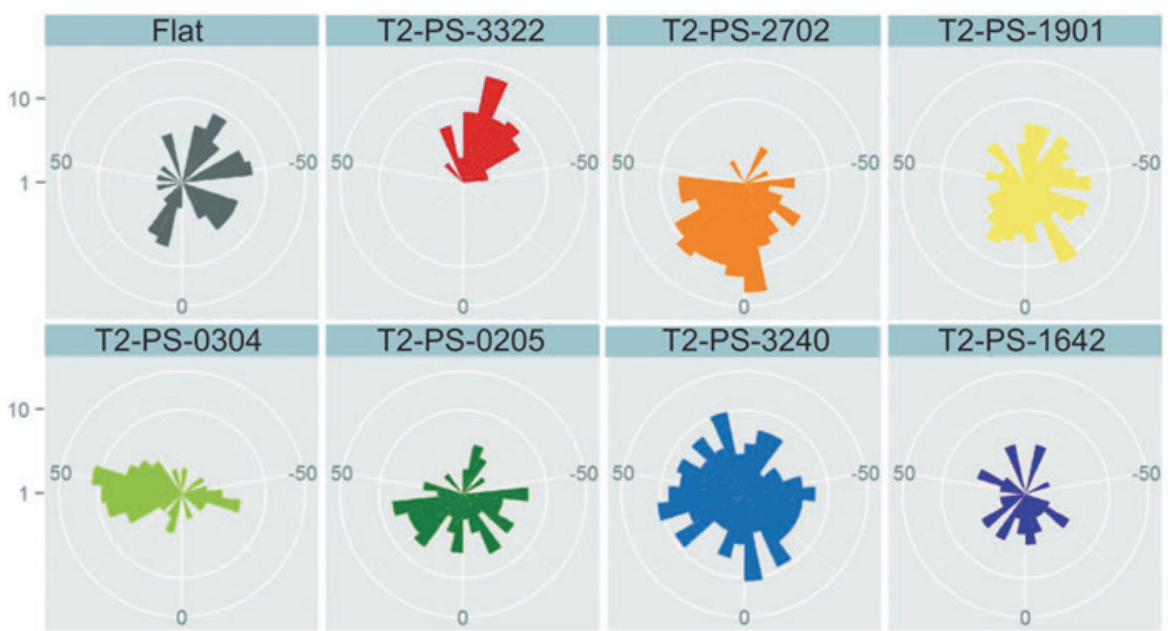

b

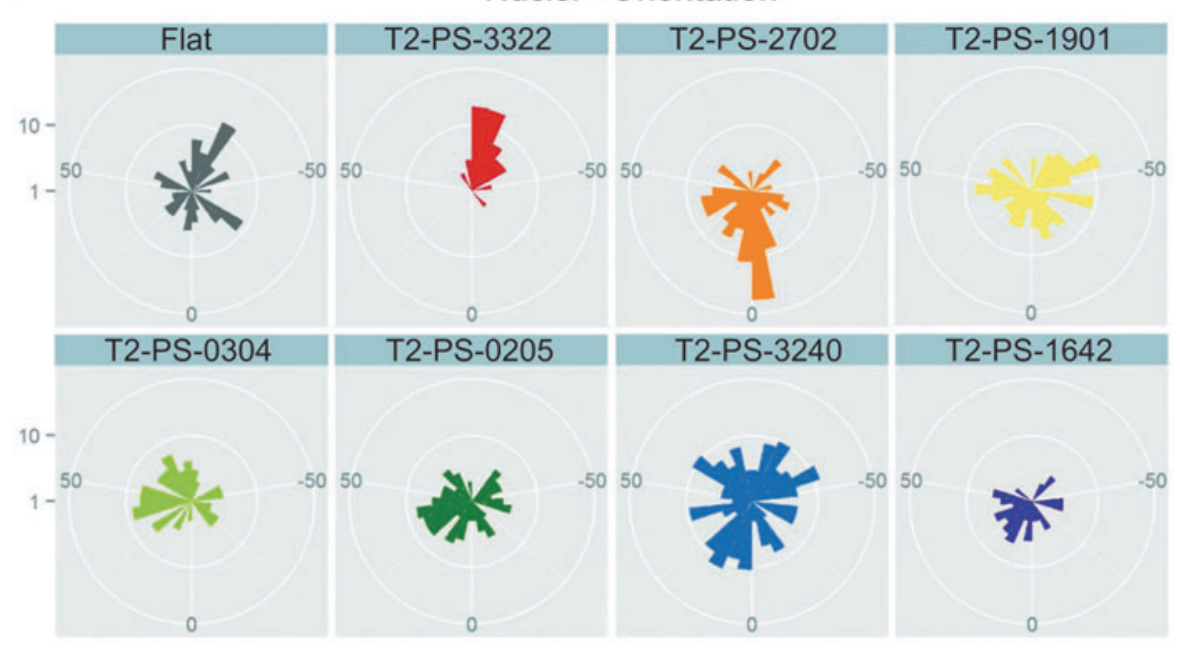

FIG. 4. Orientation of ATDC5 (a) cell and (b) nuclei grown on different surfaces in BM for $24 \mathrm{~h}$. Stained with Phalloidin and DAPI and analyzed by CellProfiler. Data were plotted in R. Cells from T2PS-3322 and T2-PS-0304 showed orientation on each surface. Nuclei on T2-PS-3322 also followed the same orientation.

\section{a}

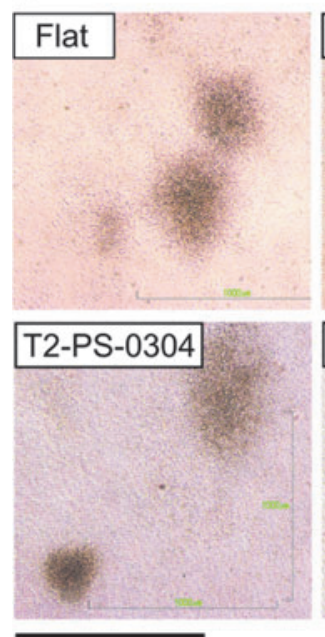

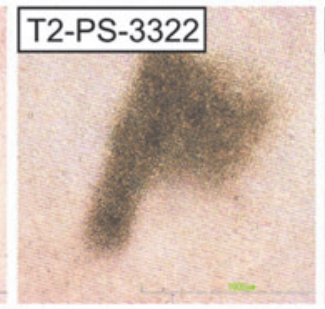

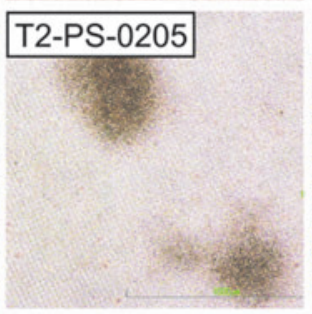

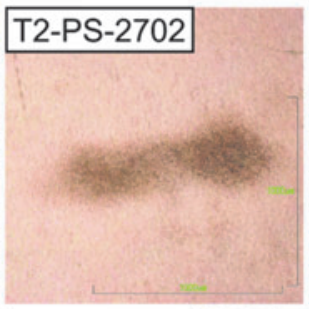

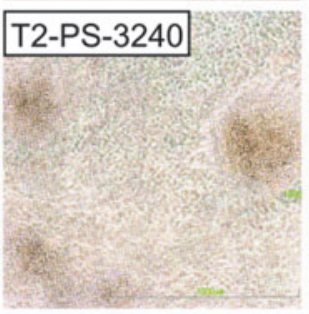

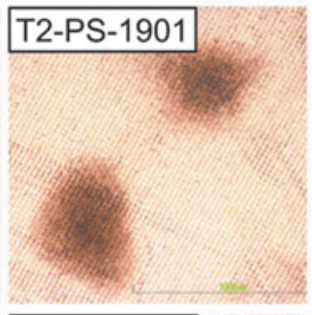

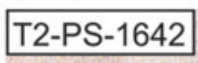

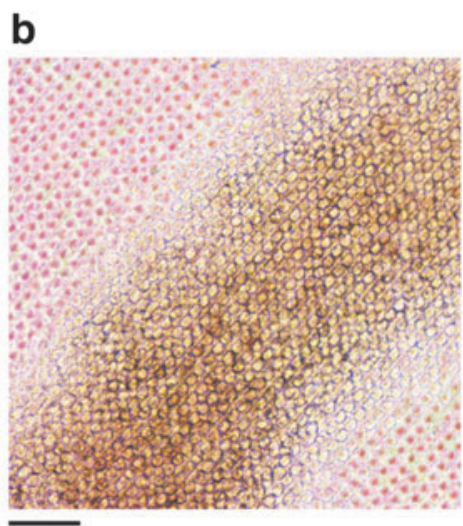

FIG. 5. Bright-field images of ATDC5 nodule formation on topographical surfaces. ATDC5 cells were cultured for 2 weeks in ITS medium. (a) Representative bright-field images of ATDC5 nodules on different surfaces, scale bar represents $1 \mathrm{~mm}$. (b) Nodule elongation on surface T2-PS-3322 aligned to the TopoUnit placement, scale bar represent $100 \mu \mathrm{m}$. 
FIG. 6. Gene expression analysis for ATDC5 cells cultured for 1 or 2 weeks on topographical surfaces in basic (blue annotated) and ITS medium ( $r e d$ annotated). qPCR analysis for early chondrogenic markers (a) collagen type II, (b) aggrecan, (c) Sox9, (d) HifIalpha and late chondrogenic markers, (e) collagen type X, (f) HifII-alpha, (g) Alp, and (h) Mmp13. Besides a few exceptions, little differences are observed at week 1 among surfaces. At week 2, the differences in gene expression among control and Topo surfaces became more pronounced when incubated together with ITS medium. Alp and Mmp13 expression on Topo surfaces outperformed the control surface in both basic and ITS medium. Error bars represent standard deviation $(n=3)$. $* p<0.05,{ }^{*} p<<0.01$, $* * * p<0.001$. ALP, alkaline phosphatase. a

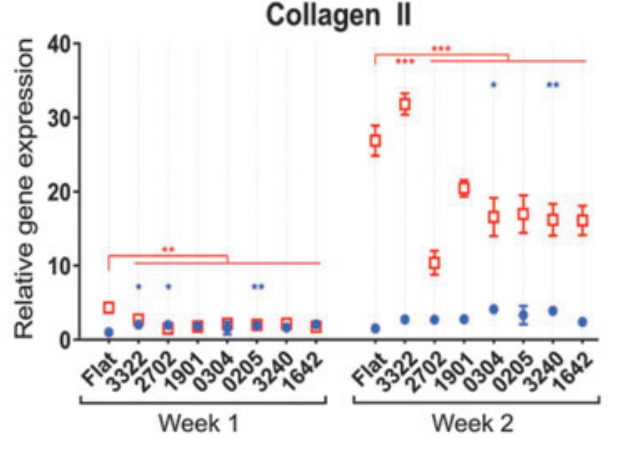

C

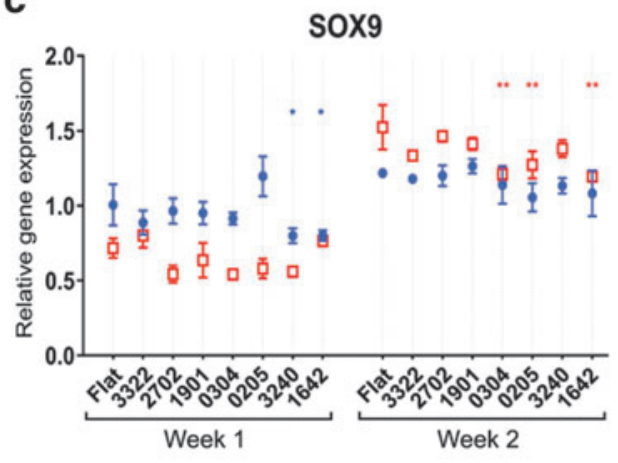

e

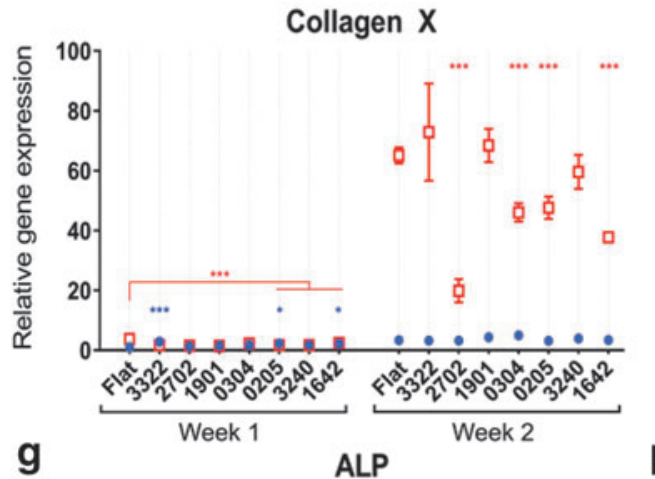

b

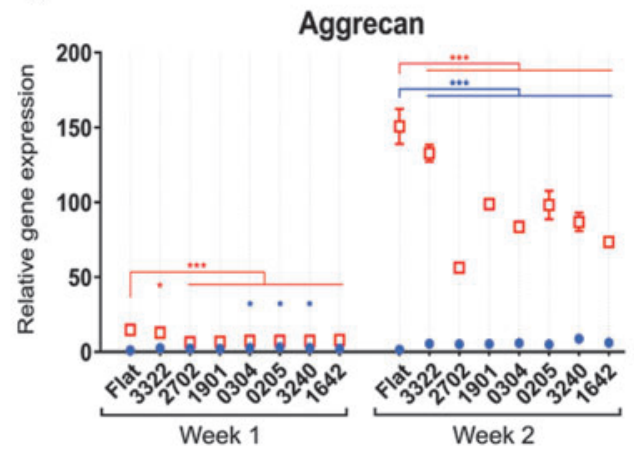

d

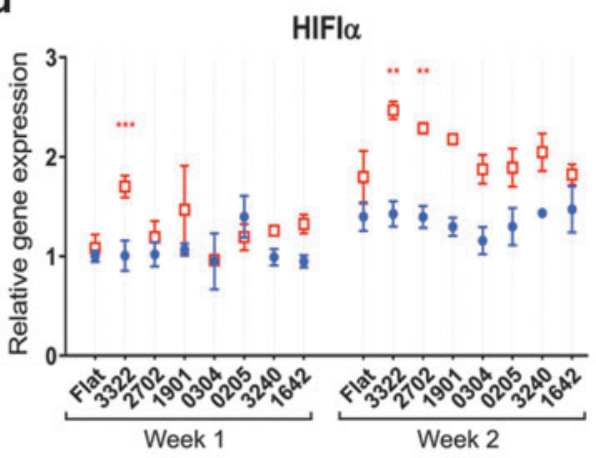

$\mathbf{f}$
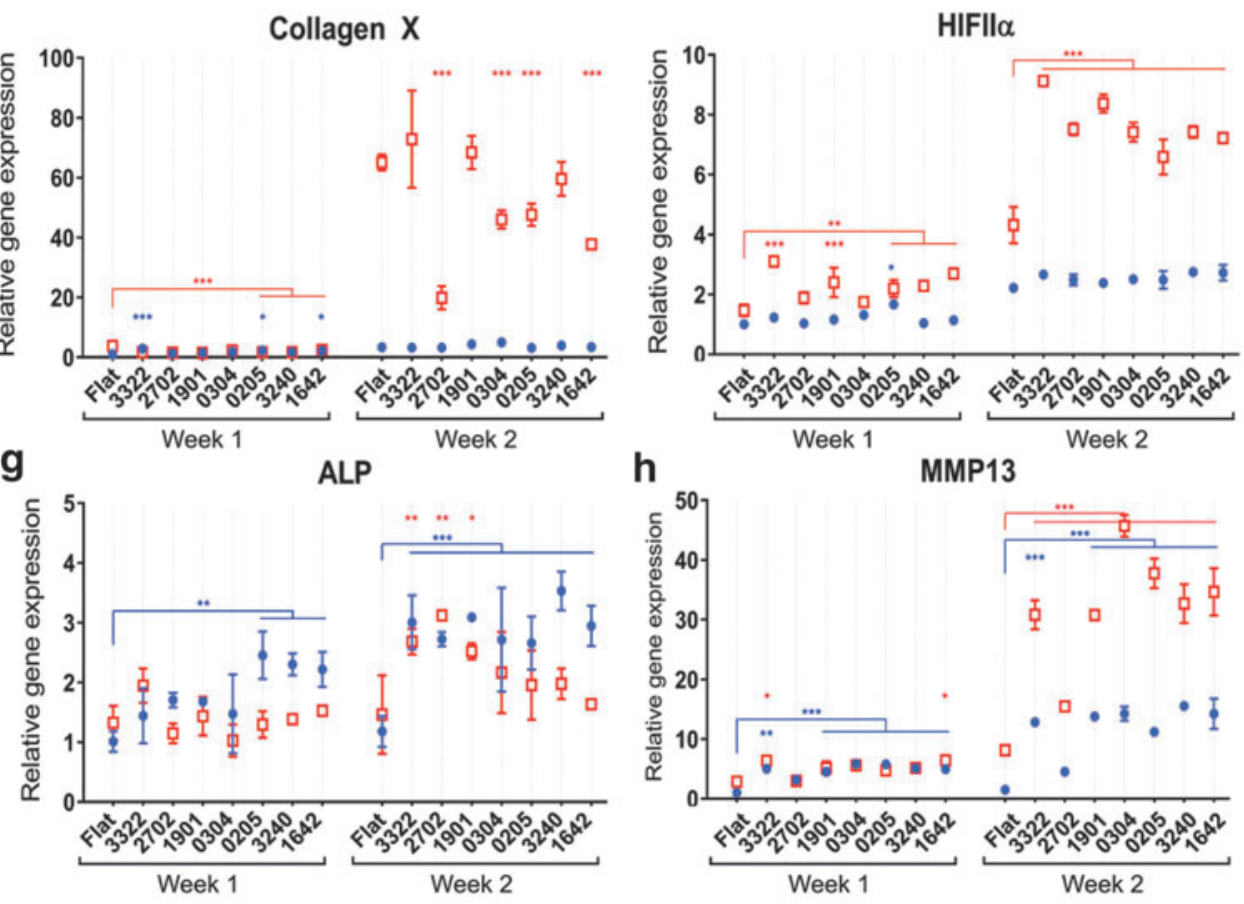

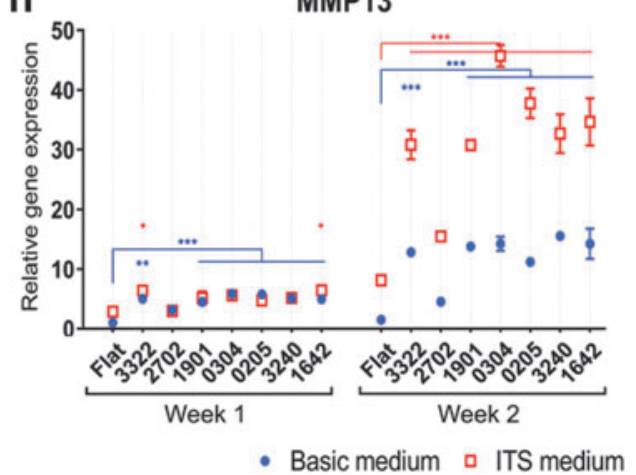

3240. Nuclei on T2-PS-3322, T2-PS-0304, T2-PS-0205, and T2-PS-1642 continued to be the smallest. Eccentricity is a measure of how elliptic cells are, where 0 represents a circle and $1 \mathrm{a}$ line. Eccentricity of cells on T2-PS-3322 was highest, and so did the nuclei of these cells. The orientation graphs (Fig. 4) illustrates the orientation of cells and nuclei on different surfaces. Cells and nuclei on the flat surface did not align in any particular direction. Only cells from T2-PS-
3322 and T2-PS-0304 were orientated on each surface. Nuclei on T2-PS-3322 also followed the same direction. Overall, these measurements allowed the quantification of unique morphologic features induced by our topographies.

ATDC5 cells can spontaneously form cell aggregatesnodules - on common tissue culture surface when stimulated with growth factors such as insulin. To evaluate whether ATDC5 nodule formation would still be possible on micro- 
a

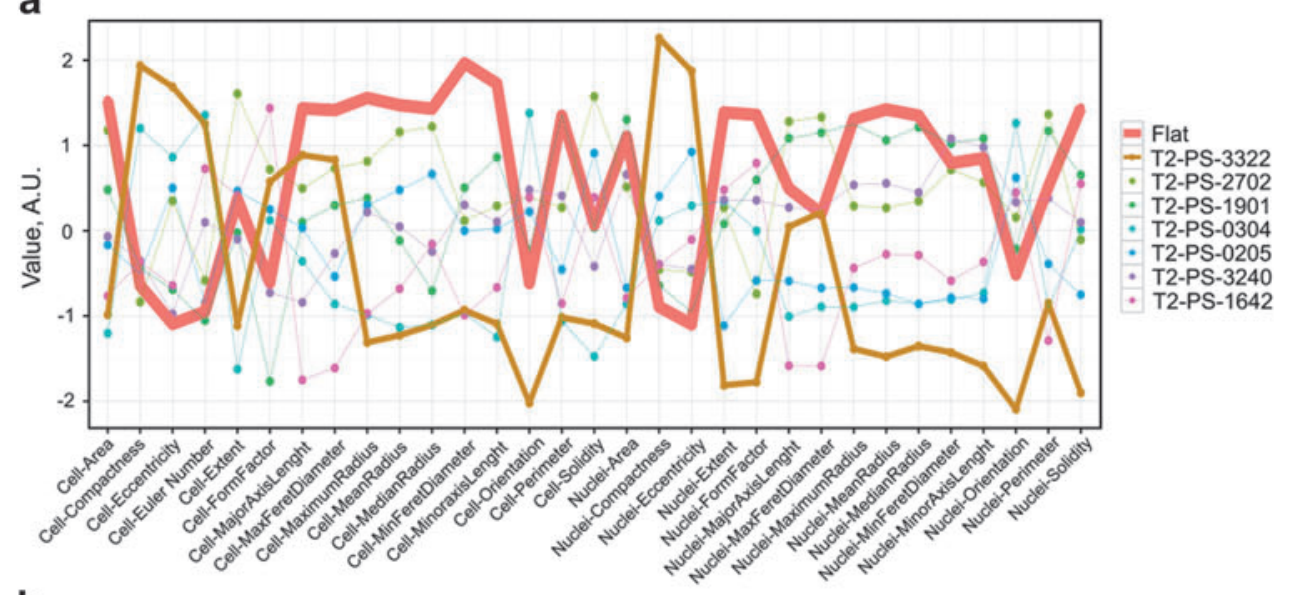

b

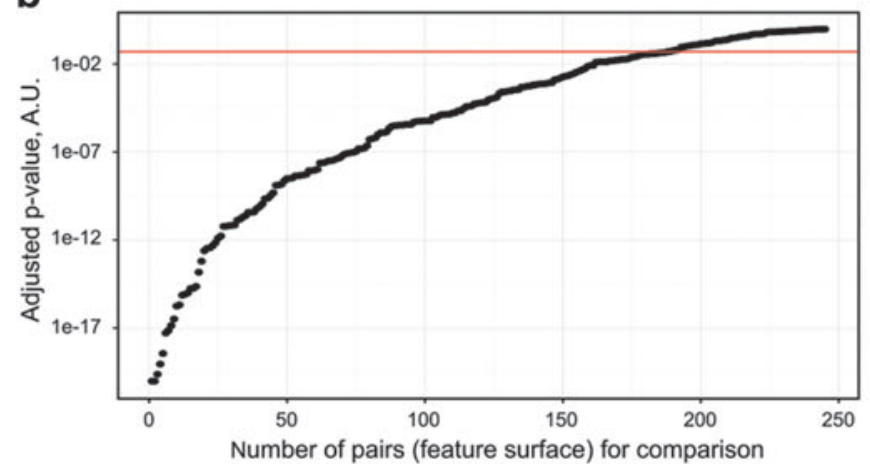

C

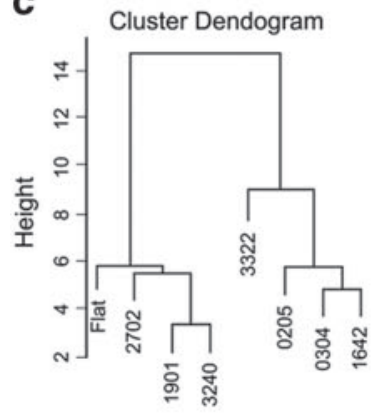

e

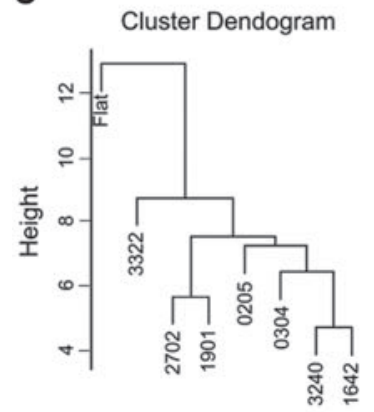

d

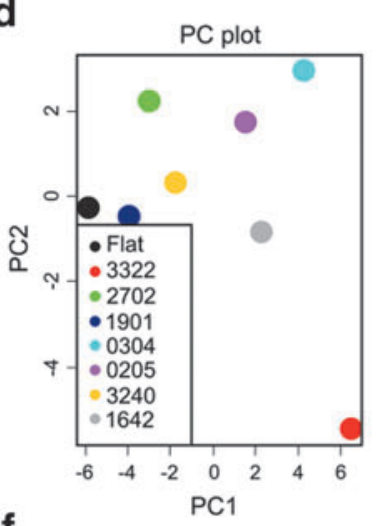

f

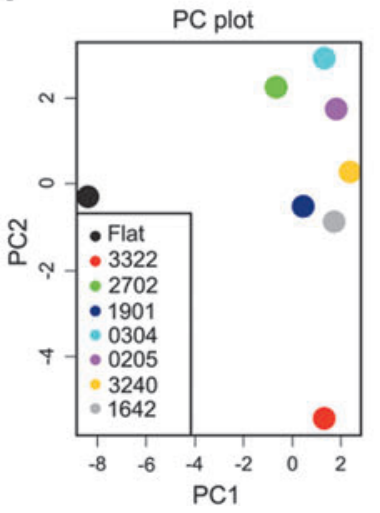

FIG. 7. Cluster dendrogram and principal component (PC) plots identified T2PS-3322 as most unique in influencing both cell morphology and gene expression. (a) Connected dotplot of scaled morphological features highlighting flat and T2-PS-3322. (b) $p$-Value plot of morphological feature comparison of topographies against flat. $p$-Values are sorted from lowest to highest. Red line represents the adjusted $p$-value, everything below is considered significant. (c) Cluster dendogram of morphological data showed clustering into two distinct groups. In the first group, the control surface was distinct from T2-PS2702, T2-PS-1901, and T2PS-3240. In the second, T2PS-3322 was separated against T2-PS-0304, T2-PS0205, andT2-PS-1642. (d)

PC analysis of morphological data revealed separation of T2-PS-3322 from other surfaces. PC plot for morphological data was calculated using median of morphological features per surface. (e) Cluster dendogram for gene expression separated control and T2-PS3322 against the other topographical surfaces. (f) PC analysis of gene expression data separated the control surface in the first PC and T2-PS-3322 in the second PC. For gene expression data, PC plots were calculated using the mean of the biological triplicate. 

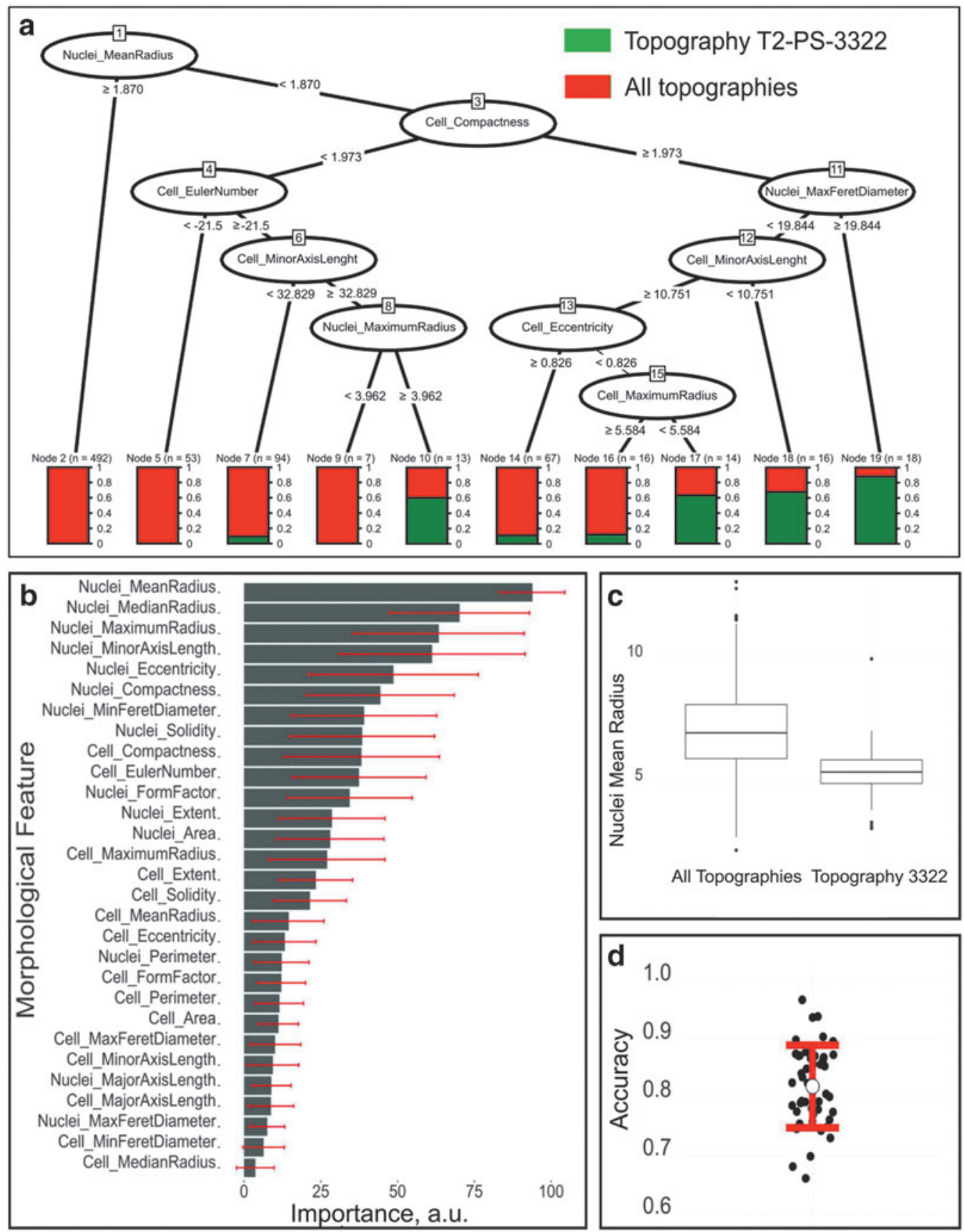

FIG. 8. Identification of unique morphology features of cells grown on T2-PS-3322. (a) Classification Tree showing the sorting of topographies by cell and nuclear morphology parameters. The nuclei mean radius is identified as the most important property that makes these cells distinct from cells grown on others surfaces. (b) Importance of cell and nuclear morphology parameters for predicting T2-PS-3322 in 100 Random Forest classification models. Bar chart represents mean \pm standard deviation. (c) Distribution of the nuclei mean radius for T2-PS-3322 and other pooled topographies. (d) Accuracy prediction of 100 Random Forest models.

topographies, we cultured ATDC5 cells on our topographical surfaces for 2 weeks in the presence of ITS. Figure 5 shows representative brightfield pictures of cell nodules on all surfaces. In general, nodule formation of ATDC5 cells on these surfaces was uneventful. Without any topography to interfere, the control surface nodules appeared mostly round. Of note, we noticed that on T2-PS-3322, the nodules elongated and aligned in one direction, which was the same direction with the alignment of the topographical units
(Fig. 5a-T2-PS-3322 and 5b). Despite having the same way of topographical unit alignment, T2-PS-2702 and T2-PS-1642 did not guide ATDC5 nodules in any particular direction.

\section{Topographies influence expression of chondrogenic genes}

To analyze the effects of topographies on ATDC5 cells in further detail, we performed gene expression analysis for 
chondrogenesis-related genes on cells grown on different surfaces in either basic or ITS medium for 1 or 2 weeks. Markers for early chondrogenesis (collagen II, aggrecan, Sox9, and HifI-alpha) and late chondrogenesis (collagen X, Alp, Mmp13, and HifII-alpha) were analyzed (Fig. 6).

At week 1, Mmp13 expression on all Topo surfaces, apart from T2-PS-2702, was higher than on flat surface in BM. However, this effect diminished when cells were treated with ITS, where only T2-PS-3322 and T2-PS-1642 remained significant. Similarly, Alp expression on T2-PS0205, T2-PS-3240, and T2-PS-1642 was higher than on control surface in basic but not in ITS medium. For HifIIalpha, a slight increase was observed for T2-PS-0205 in BM. This effect was more pronounced after ITS treatment, causing a significant HiffII-alpha upregulation for T2-PS-3322, T2-PS-1901, T2-PS-0205, T2-PS-3240, and T2-PS-1642.

At week 2, the differences in gene expression among the control and Topo surfaces were more pronounced. Expression of chondrogenic genes upregulated over time and was higher in ITS medium. In BM, the effect of topography on chondrogenic gene expression was mild; little difference was seen between topographical surfaces and control surface except for Alp and Mmp13, where expressions on Topo surfaces were all higher, aside from T2-PS-1901. In ITS medium, the difference in gene expression among Topo and control surfaces were greater. Most Topo surfaces induced expression of the late markers HifIIalpha, Alp, and Mmp13, but inhibited expression of the early markers collagen II, aggrecan, and in some cases Sox9.

In general, gene expression profiles of cells on different Topo surfaces were distinct from one another, which was the same observation as for cell and nuclei shape features. Topo surfaces induced higher expression of late chondrogenic markers (except for collagen X), but inhibited expression of early markers compared to the control surface.

\section{Correlation of morphology and gene expression}

To find out which topography imposed the most significant changes in either cell morphology or gene expression, we performed principal component analysis. For morphology data, we considered the median of all morphological features per surface. Gene expression data were visualized using the mean of the biological triplicate of all genes in both basic and ITS medium for each surface. Surface similarity based on cell and nuclear morphology was visualized by hierarchical dendrogram clustering (Fig. 7c). Cell and nuclear morphologies could be clustered into two distinct groups. In the first group, cell and nuclear morphologies from the control surface were different from T2-PS-2702, T2-PS-1901, and T2-PS-3240. In the other, it was T2-PS3322 vs. T2-PS-0304, T2-PS-0205, and T2-PS-1642. In the plot for morphology data (Fig. 7d), T2-PS-3322 was very well separated from all other surfaces in the first two principal components (PC1 and PC2). T2-PS-3322 stood out as the surface that was most distinct in cell and nuclear morphologies compared to other surfaces according to image analysis by CellProfiler.

The same analysis was performed for gene expression data (Fig. 7e, f). The control surface was well separated from all topographies in the first principal component (PC1), while T2-PS-3322 was separated in the second principal component (PC2). Hierarchical clustering revealed that the control surface was substantially different from the others in inducing gene expression. Among the Topo group, T2-PS3322 was again well separated from the other topographical surfaces. Thus, together with the morphological data analysis, T2-PS-3322 was unique in influencing both cell morphology and chondrogenic gene expression of ATDC5. This separation of T2-PS-3322 in gene expression profiles appeared to be caused by the upregulation of both early and late chondrogenic markers.

To understand which morphological features makes cells on T2-PS-3322 unique, we constructed a classification tree based on morphology data (Fig. 8a). We used this classification tree to understand which cell shape parameters were related to the cells on T2-PS-3322. Almost $90 \%$ of cells with cell compactness $\geq 1.97$ and nuclei maximum Feret diameter $\geq 19.84 \mu \mathrm{m}$ belonged to T2-PS-3322. This means that cells on T2-PS-3322 shared the largest variation in distance between cell border and center than cells on other surfaces. The maximum Feret diameter is a measure of nuclear length; it was suggested that nuclei on T2-PS-3322 were elongated, supported by Figure $5 \mathrm{~d}$. About $70 \%$ of cells with a maximum Feret diameter $<19.84 \mu \mathrm{m}$ and a cell minor-axis-length $<10.75 \mu \mathrm{m}$ were also found on T2-PS3322. Cell minor-axis-length also attributed to cell shape narrowness and elongation. Cells that were not as thick as the previous group were less eccentric $(<0.82)$ and at the same time the cell maximum radius was less than $5.85 \mu \mathrm{m}$. Sixty percent of these cells were on T2-PS-3322. These might be mitotic cells. Last major set of parameters of which discriminates cells with $60 \%$ accuracy on T2-PS-3322 are as follows: cell compactness $<1.97$, Euler number $>21.5$, cell minor axis length $>32.8 \mu \mathrm{m}$, and a nuclei maximum radius $>4.0 \mu \mathrm{m}$. The combination of these factors suggested that these cells have an irregular shape with big nuclei; these are apparently cells lying on top of the patterns. Furthermore, we trained 100 machine learning models to distinguish cells morphology from T2-PS-3322 and the other topographies. We found that the most important morphological feature for that analysis was the nuclei mean radius (Fig. 8b, c). The mean accuracy of these models was $81 \%$ (Fig. 8d), which indicates that cell response on T2-PS-3322 was unique and can be accurately predicted using cell morphological features.

\section{Discussion}

In the growth plate, proliferation and differentiation of chondrocytes are tightly controlled by soluble factors such as Indian hedgehog, parathyroid hormone-related protein, and bone morphogenetic proteins. ${ }^{26-28}$ Likewise, ECM protein receptors on chondrocytes, such as $\beta 1$ integrins, regulate cell arrangement into the regular longitudinal column of proliferative chondrocytes. ${ }^{29}$ Mechanical loading also plays an important role in controlling the growth of this hypertrophic plate. ${ }^{30,31}$ It is known that cell shape is important for chondrocyte function, ${ }^{32,33}$ however, little is known about the influence of surface topography, or rather ECM topography, on the development of chondrocytes in the body. When cells are exposed to a foreign environment, it is inevitable that they lack their usual trophic signals. Here, material surface topography becomes an inherent foreign signal existing in all artificial systems. Once harnessed, 
surface topography can then be utilized as an instructive signal for chondrocyte growth and hypertrophic differentiation.

In this study, we investigated the effect of seven designed surface micro-topographies on the chondrogenic differentiation process of ATDC5 cells. These seven topographies were selected from the hits of our previous high-throughput screen for topographies. In this previous screen, four of these hits induced ALP secretion of hMSCs (T2-PS-3322, T2-PS-0304, T2-PS-0205, and T2-PS-1642), while three did not show any influence (T2-PS-2702, T2-PS-1901, and T2PS-3240). Note that in this study, ALP expression is induced differently by our topographies. This likely reflects the different cell type used or the influence of different surface chemistry on cell behavior. ALP is often used as an in vitro marker for osteogenic differentiation of MSCs, but $A L P$ is also a marker for hypertrophic differentiation of chondrocytes. $^{34,35}$ In this study, we show that ATDC5 cells cultured on the Topo surfaces can significantly influence the expression of $A L P$ and other late markers of chondrogenesis, supporting our hypothesis that surface topography can influence the differentiation of chondrocytes.

Chondrocyte aggregation in vitro is a process mimicking mesenchymal condensation in vivo. Keeping the cell-to-cell contact has been shown to be a prerequisite of chondrogenesis. Hamilton et al. used a micro-topography silica substrate with grooves measuring 0.75 to $8 \mu \mathrm{m}$ in depth and 5 to $12.5 \mu \mathrm{m}$ in width-to control aggregation of primary chondrocytes. $^{36}$ They noted that larger aggregates collided with each other on the groove and often in parallel to the direction of the groove. We also found that ATDC5 grown on T2-PS-3322 formed aggregates, which elongated in parallel to the alignment of the topographical patterns. Although all seven Topo surfaces had the same pattern arrangement, the ATDC5 aggregate elongation only appeared on T2-PS-3322, suggesting that the size of the pattern itself affected this observation. The implications of nodule alignment can be the subject of further studies.

In vitro, cell morphology is paramount to cell growth, as demonstrated by Folkman and Moscona in one of the earliest experiments proving the relationship between cell shape and DNA synthesis. ${ }^{4}$ In their experiments, the cell shape changed from flat to spheroidal as the result of reduced adhesion to the culture plate. Since our topographical surfaces were made of PS, the standard tissue culture material, cells adhered very well and thus the topography often served as a mold encasing the cells. Often, actin was very intensely stained around the wall of the topography or in the grooves created by the topography patterns. The cell nuclei also adapted the shape of the topography. CellProfiler analysis showed a large variation in cell and nuclei features among the seven Topo surfaces. Interestingly, our gene expression set followed the same trend. To elucidate the effect of cell morphology on gene expression, our strategy involved analyzing a dataset of 30 cell morphological features and correlating these with a gene expression dataset of early and late markers for chondrogenesis. The problem remains that gene expression analysis is based on averaging gene expression of all the cells on one single surface, which at times can vary considerably. The use of single-cell polymerase chain reaction may be the answer to overcome this problem.
We conclude that the use of micro-topographies can influence the expression of early and late markers for chondrogenesis. In combination with soluble factors, these topographies can be used to control chondrogenic differentiation of ATDC5 cells in vitro. Since our research was based on only seven topographies, future studies with different topographies and chemistry could further fine-tune the optimal surface architecture for hypertrophic differentiation.

\section{Acknowledgments}

J.d.B. acknowledges the financial support of the Dutch province of Limburg, F.H. the NanoNext initiative, A.V. the European Union's Seventh Framework Programme (FP7/ 2007-2013; Grant agreement 289720), and S.V. the European Union's Horizon 2020 Programme (H2020-MSCAITN-2015; Grant agreement 676338). We appreciate the financial support for our studies as part of the PIDON project (PID091014) issued by the Dutch State, the Ministry of Economic affairs.

\section{Disclosure Statement}

C.A.v.B. and J.d.B. are co-founders of, and have a financial interest in, Materiomics b.v. The other authors do not have any financial interests to declare.

\section{References}

1. McBeath, R., Pirone, D.M., Nelson, C.M., Bhadriraju, K., and Chen, C.S. Cell shape, cytoskeletal tension, and RhoA regulate stem cell lineage commitment. Dev Cell 6, 483, 2004.

2. Dalby, M.J., Gadegaard, N., Tare, R., Andar, A., Riehle, M.O., Herzyk, P. Wilkinson, C.D.W., and Oreffo, R.O.C. The control of human mesenchymal cell differentiation using nanoscale symmetry and disorder. Nat Mater 6, 997, 2007.

3. Marklein, R.A., and Burdick J.A. Controlling stem cell fate with material design. Adv Mater 22, 175, 2010.

4. Folkman, J., and Moscona, A. Role of cell shape in growth control. Nature 273, 345, 1978.

5. Damanik, F.F.R, Rothuizen, T.C., van Blitterswijk, C.A., Rotmans, J.I., and Moroni, L. Towards an in vitro model mimicking the foreign body response: tailoring the surface properties of biomaterials to modulate extracellular matrix. Sci Rep 4, 6325, 2014.

6. Yang, L., Hedhammar, M., Blom, T., Leifer, K., Johansson, J., Habibovic, P., and van Blitterswijk, C.A. Biomimetic calcium phosphate coatings on recombinant spider silk fibres. Biomed Mater 5, 045002, 2010.

7. Shibata, Y., and Tanimoto, Y. A review of improved fixation methods for dental implants. Part I: surface optimization for rapid osseointegration. J Prosthodont Res 59, 20, 2015.

8. Wennerberg, A., and Albrektsson T. Effects of titanium surface topography on bone integration: a systematic review. Clin Oral Implants Res 20 Suppl 4, 172, 2009.

9. Albrektsson, T., Branemark, P.I., Hansson, H.A., and Lindström, J. Osseointegrated titanium implants. Requirements for ensuring a long-lasting, direct bone-to-implant anchorage in man. Acta Orthop Scand 52, 155, 1981.

10. Unadkat, H.V., Hulsman, M., Cornelissen, K., Papenburg, B.J., Truckenmüller, R.K., Carpenter, A.E., Wessling, M., Post, G., Uetz, M., Reinders, M.J.T., Stamatialis, D., van Blitterswijk, C.A., and de Boer, J. An algorithm-based to- 
pographical biomaterials library to instruct cell fate. Proc Natl Acad Sci U S A 108, 16565, 2011.

11. Pfander, D., Swobodam, B., and Kirsch, T. Expression of early and late differentiation markers (proliferating cell nuclear antigen, syndecan-3, annexin VI, and alkaline phosphatase) by human osteoarthritic chondrocytes. Am J Pathol 159, 1777, 2001.

12. Jukes, J.M., Both, S.K., Leusink, A., Sterk, L.M.T., van Blitterswijk C.A., and de Boer J. Endochondral bone tissue engineering using embryonic stem cells. Proc Natl Acad Sci U S A 105, 6840, 2008.

13. Yao, Y., and Wang, Y. ATDC5: an excellent in vitro model cell line for skeletal development. J Cell Biochem 114, 1223, 2013.

14. Le, B.Q., Fernandes, H., Bouten, C.V.C., Karperien, M., van Blitterswijk, C.A., and de Boer, J. High-throughput screening assay for the identification of compounds enhancing collagenous extracellular matrix production by ATDC5 cells. Tissue Eng Part C Methods 21, 726, 2015.

15. Hatakeyam, Y., Matsuda Y., Hatakeyama J., Oka K., Anan H., Tsuruga E., Inai T., Ishikawa H., and Sawa Y. The effect of growth differentiation factor-5, 6, 7 in chondrogenic cell differentiation of ATDC-5. Am J Biosc 2, 182, 2014.

16. Altaf, F.M., Hering, T.M., Kazmi, N.H., Yoo, J.U., and Johnstone, B. Ascorbate-enhanced chondrogenesis of ATDC5 cells. Eur Cells Mater 12, 64, 2006.

17. Portron, S., Hivernaud, V., Merceron, C., Lesoeur, J., Masson, M., Gauthier, O., Vinatier C., Beck V., and Guicheux J. Inverse regulation of early and late chondrogenic differentiation by oxygen tension provides cues for stem cell-based cartilage tissue engineering. Cell Physiol Biochem 35, 841, 2015.

18. Kwon, H.J., Yasuda, K., Ohmiya, Y., Honma, K., Chen, Y.M., and Gonge, J.P. In vitro differentiation of chondrogenic ATDC5 cells is enhanced by culturing on synthetic hydrogels with various charge densities. Acta Biomater 6, 494-501, 2010.

19. Hulsman, M., Hulshof, F., Unadkat, H., Papenburg, B.J., Stamatialis, D.F., Truckenmüller, R., van Blitterswijk C., de Boer J., and Reinders M.J.T. Analysis of high-throughput screening reveals the effect of surface topographies on cellular morphology. Acta Biomater 15, 29, 2015.

20. Abagnale, G., Steger, M, Nguyen, V.H., Hersch, N., Sechi, A., Joussen, S., Denecke, B., Merkel, R., Hoffmann, B., Dreser, A., Schnakenberg, U., Gillner, A., and Wagner, W. Surface topography enhances differentiation of mesenchymal stem cells towards osteogenic and adipogenic lineages. Biomaterials 61, 316, 2015.

21. Carpenter, A.E., Jones, T.R., Lamprecht, M.R., Clark, C., Kang, I.H., Friman, O., Guertin, A.D., Chang, J.H., Lindquist, R.A., Moffat, J., Golland, P., and Sabatini, D.M. CellProfiler: image analysis software for identifying and quantifying cell phenotypes. Genome Biol 7, R100, 2006.

22. R Core Team. R: A language and environment for statistical computing. Vienna, Austria: R Foundation for Statistical Computing, 2009.

23. Shah, J.V. Cells in tight spaces: the role of cell shape in cell function. J Cell Biol 191, 233, 2010.
24. Cadart, C., Zlotek-Zlotkiewicz, E., Le Berre, M., Piel, M., and Matthews, H.K. Exploring the function of cell shape and size during mitosis. Dev Cell 29, 159, 2014.

25. Lecuit, T., and Lenne, P.F. Cell surface mechanics and the control of cell shape, tissue patterns and morphogenesis. Nat Rev Mol Cell Biol 8, 633, 2007.

26. Minina, E., Wenzel, H.M., Kreschel, C., Karp, S., Gaffield, W., McMahon, A.P., and Vortkamp, A. BMP and Ihh/PTHrP signaling interact to coordinate chondrocyte proliferation and differentiation. Development 128, 4523, 2001.

27. Caron, M.M.J., Emans, P.J., Cremers, A., Surtel, D.A.M., Coolsen, M.M.E., van Rhijn, L.W., and Welting T.J.M. Hypertrophic differentiation during chondrogenic differentiation of progenitor cells is stimulated by BMP-2 but suppressed by BMP-7. Osteoarthr Cartil 21, 604, 2013.

28. Chen, X., Macica, C.M., Nasiri, A., and Broadus, A.E. Regulation of articular chondrocyte proliferation .and differentiation by indian hedgehog and parathyroid hormonerelated protein in mice. Arthritis Rheum 58, 3788, 2008.

29. Aszodi, A., Hunziker, E.B., Brakebusch, C., and Fässler, R. Beta1 integrins regulate chondrocyte rotation, G1 progression, and cytokinesis. Genes Dev 17, 2465, 2003.

30. Frost, H.M. Skeletal structural adaptations to mechanical usage (SATMU): 3. The hyaline cartilage modeling problem. Anat Rec 226, 423, 1990.

31. Villemure, I., and Stokes I.A. Growth plate mechanics and mechanobiology. A survey of present understanding. J Biomech 42, 1793, 2009.

32. Glowacki, J., Trepman E., and Folkman J. Cell shape and phenotypic expression in chondrocytes. Proc Soc Exp Biol Med 172, 93, 1983.

33. Guo, H., and Torzilli, P.A. Shape of chondrocytes within articular cartilage affects the solid but not the fluid microenvironment under unconfined compression. Acta Biomater 29, 170, 2016.

34. Goldring, M.B., Tsuchimochi K., and Ijiri K. The control of chondrogenesis. J Cell Biochem 97, 33, 2006.

35. Dreier, R. Hypertrophic differentiation of chondrocytes in osteoarthritis: the developmental aspect of degenerative joint disorders. Arthritis Res Ther 12, 216, 2010.

36. Hamilton, D.W., Riehle, M.O., Monaghan, W., and Curtis, A.S. Chondrocyte aggregation on micrometric surface topography: a time-lapse study. Tissue Eng 12, 189, 2006.

Address correspondence to: Steven Vermeulen, MSc Laboratory for Cell Biology-inspired Tissue Engineering MERLN Institute

University of Maastricht P.O. Box 616

Maastricht 6200 MD The Netherlands

E-mail: s.vermeulen@maastrichtuniversity.nl

Received: October 11, 2016

Accepted: January 24, 2017

Online Publication Date: March 10, 2017 